\title{
Novel hybrid composites based on polypropylene with basalt/carbon fiber (Rapid communication)
}

\author{
Stanisław Kuciel ${ }^{1), *)}$, Anna Kufel ${ }^{1)}$ \\ DOI: dx.doi.org/10.14314/polimery.2018.5.8
}

\begin{abstract}
Hybrid composites based on the homopolymer polypropylene Moplen HP500N reinforced with a mixture of basalt and carbon fibers in weight content of 10, 15 and $20 \%$ were produced by injection molding. The density of these composites, their shrinkage and the Vicat softening temperature were determined. Tests of tensile and bending strength properties were carried out and Charpy impact was determined at three temperatures: $-24,22$ and $80^{\circ} \mathrm{C}$. SEM images were taken to assess the effects of reinforcement and homogenization of composites and to determine the characteristics of their microstructure. Light-weight hybrid composites with already $10 \mathrm{wt} \%$ basalt fibers and $10 \mathrm{wt} \%$ carbon fibers are characterized by more than two and a half times increase in strength and over four times increase of the modulus of elasticity in a wide range of temperatures.
\end{abstract}

Keywords: polypropylene, hybrid composite, mechanical properties.

\section{Hybrydowe kompozyty na osnowie polipropylenu wzmacniane włóknami bazaltowymi i węglowymi}

\begin{abstract}
Streszczenie: Wytworzono metodą wtryskiwania hybrydowe kompozyty homopolimeru polipropylenowego Moplen HP500N wzmacniane mieszaniną włókien bazaltowych i węglowych o udziale wagowym 10, 15 i $20 \%$. Wyznaczono gęstość wytworzonych kompozytów, ich skurcz oraz temperaturę mięknienia Vicata. Wykonano badania właściwości wytrzymałościowych przy rozciąganiu i zginaniu oraz oznaczono udarność wg Charpy`ego w temperaturze: -24, 22 i $80^{\circ} \mathrm{C}$. W celu oceny efektów wzmocnienia oraz homogenizacji kompozytów i oznaczenia cech ich mikrostruktury wykonano mikrofotografie SEM. Stwierdzono, że w przypadku lekkich hybrydowych kompozytów z włóknami bazaltowymi i węglowymi już 10-proc. udział włókien powoduje ponad dwu i pół krotne zwiększenie wytrzymałości oraz ponad czterokrotne zwiększenie modułu sprężystości w szerokim zakresie temperatury.
\end{abstract}

Słowa kluczowe: polipropylen, kompozyty hybrydowe, właściwości wytrzymałościowe.

Short-fiber reinforced polymer (SFRP) composites are very attractive because of their simplicity of production, low-cost and good mechanical properties. Extrusion compounding and injection molding are frequently employed to make SFRP composites [1]. Hybrid composites are made by adding two or more different types of fillers in a single matrix [2]. Furthermore, hybrid composites offer a better balance in mechanical properties than non-hybrid composites [3]. Nowadays, few studies have been conducted on the hybridization of wood-polymer composites (WPC) [4-8]. Guo et al. reported that using a small amount of carbon fibers (e.g., 5-10 wt \%) enhances mechanical properties of WPC and the usa-

1) Cracow University of Technology, Faculty of Mechanical Engineering, Institute of Materials Engineering, al. Jana Pawła II 37, 31-864 Kraków, Poland.

*) Author for correspondence; e-mail: stask@mech.pk.edu.pl ge of wood fibers in carbon-fiber composites can reduce high cost while enhancing toughness [2]. Furthermore, Yan et al. studied polypropylene-glass fiber/carbon fiber hybrid composites fabricated by a new method called direct fiber feeding injection molding [9]. New possibilities of using the filler are basalt fibers in hybrid composites because of their resistance and thermal stability higher than glass fibers and good adhesion to polypropylene matrix [10]. Basalt fibers are well compatible with other materials and many complex materials can be made with them [11]. Greco et al. studied adhesion properties of basalt and glass fibers in polypropylene matrix [12]. Basalt fibers have higher adhesion than sized glass fibers, and comparable to carbon fibers. In all cases, it was highlighted that the adhesion properties can be significantly improved by increasing the polarity of the polymer matrix. Carbon fibers are very stable, stiff and strong and also thermally stable and can withstand a wide range of tem- 
perature. This is why there are used as reinforcement in loading elements where special requirements are specified, e.g., in aerospace and military industry [13-14]. Until now, researches on the basalt fiber/carbon fiber reinforcement on polypropylene matrix are not known. This type of solution is used in woven hybrid epoxy composites to decrease cost of production and to increase thermal resistance [15]. Carbon/glass, kevlar/basalt and flax/basalt reinforcements are also used as hybrid composites laminates [16-17]. In thermoplastic composites with short-fiber reinforcement, which are produced by injection molding, it is very important to add a suitable compatibilizer [18]. Maleic anhydride polypropylene (MAPP) has been used as a coupling agent to improve the interfacial interaction between the fibers and matrix [19]. Kada et al. studied the effect of MAPP on properties of wood fiber/ carbon fiber hybrid composites [4]. The composites without MAPP showed a lower stiffness, lower strength and higher water absorption than the coupled ones. Zhang et al. reported that polypropylene (PP) hybrid composites with anhydride-grafted PP filled with wood fibers and short glass fibers had better mechanical properties than hybrid composites with other coupling agents for example with glycidyl methacrylate-grafted PP [20].

The aim of the study is to investigate the effect of two kinds fillers, basalt and carbon fibers, on the mechanical and physical properties of carbon/basalt composite on po- lypropylene matrix in a wide range temperature. Effects of addition of short carbon/basalt fibers on the mechanical, processing and morphological properties of polypropylene composites were investigated. Longer and thicker basalt fibers may connect a greater area of composite microstructure, while shorter and thinner carbon fibers may connect smaller area. Both of these mechanisms improve strength properties and it was proved in the researches.

\section{EXPERIMENTAL PART}

\section{Materials}

In this investigation PP (Moplen HP500N), carbon fibers (Zoltek PX35), and basalt fibers (Basaltex BCS17-6.4KV16) were used. Anhydride maleic PP (SCONA TPPP 9112 GA) supplied by Byk (Altana Group) was used as a compatibilizer.

\section{Methods of testing}

Standard dumbbell samples were molded using the Engel ES 200/40 injection molding machine after compounding fibers and polypropylene by means of a twin screw extruder. The temperatures in the subsequent zones ranged from 180 to $220^{\circ} \mathrm{C}$ and the injection speed ranged from 60 to $90 \mathrm{~mm} / \mathrm{s}$.

$\mathrm{T}$ a b l e 1. Composition and basic physical and processing properties of the materials

\begin{tabular}{|c|c|c|c|c|}
\hline Index & Composition & $\begin{array}{l}\text { Density } \\
\mathrm{g} / \mathrm{cm}^{3}\end{array}$ & $\begin{array}{l}\text { Vicat softening } \\
\text { temperature, }{ }^{\circ} \mathrm{C}\end{array}$ & $\begin{array}{c}\text { Shrinkage } \\
\%\end{array}$ \\
\hline PP & Neat PP Moplen HP500N & 0.886 & 150.6 & 1.7 \\
\hline PP5B5C & $\begin{array}{l}\text { PP Moplen HP500N }+5 \mathrm{wt} \% \text { basalt fibers } \\
+5 \mathrm{wt} \% \text { carbon fibers }+3 \mathrm{wt} \% \text { MAPP }\end{array}$ & 0.943 & 159.4 & 0.7 \\
\hline PP7B7C & $\begin{array}{l}\text { PP Moplen HP500N }+7.5 \mathrm{wt} \% \text { basalt fibers } \\
+7.5 \mathrm{wt} \% \text { carbon fibers }+3 \mathrm{wt} \% \text { MAPP }\end{array}$ & 0.963 & 160.7 & 0.6 \\
\hline PP10B10C & $\begin{array}{l}\text { PP Moplen HP500N }+10 \mathrm{wt} \% \text { basalt fibers } \\
+10 \mathrm{wt} \% \text { carbon fibers }+3 \mathrm{wt} \% \text { MAPP }\end{array}$ & 1.009 & 163.8 & 0.5 \\
\hline
\end{tabular}

T a b l e 2. Mechanical properties of the tested materials

\begin{tabular}{|c|c|c|c|c|c|}
\hline Index & $\begin{array}{c}\text { Temperature } \\
{ }^{\circ} \mathrm{C}\end{array}$ & $\begin{array}{c}\text { Tensile strength } \\
\mathrm{MPa}\end{array}$ & $\begin{array}{c}\text { Tensile modulus } \\
\mathrm{MPa}\end{array}$ & $\begin{array}{c}\text { Strain at break } \\
\%\end{array}$ & $\begin{array}{c}\text { Unnotched Charpy } \\
\text { impact strength } \\
\mathrm{kJ} / \mathrm{m}^{2}\end{array}$ \\
\hline \multirow{3}{*}{ PP } & -24 & $44.0 \pm 3.8$ & $3963 \pm 82$ & $10.8 \pm 0.5$ & $13.1 \pm 1.8$ \\
\hline & 22 & $28.7 \pm 0.2$ & $1559 \pm 42$ & $>200$ & $77.3 \pm 25.0$ \\
\hline & 80 & $18 \pm 0.5$ & $537 \pm 35$ & $>200$ & no break \\
\hline \multirow{3}{*}{ PP5B5C } & -24 & $88 \pm 2.7$ & $7619 \pm 241$ & $2.9 \pm 0.1$ & $19.3 \pm 3.1$ \\
\hline & 22 & $55.6 \pm 3$ & $4481 \pm 365$ & $2.6 \pm 0.1$ & $27.9 \pm 5.2$ \\
\hline & 80 & $35.1 \pm 0.1$ & $3114 \pm 33$ & $2.4 \pm 0.1$ & $33.5 \pm 1.0$ \\
\hline \multirow{3}{*}{ PP7B7C } & -24 & $92 \pm 1.7$ & $8533 \pm 570$ & $2.9 \pm 0.1$ & $17.8 \pm 1.7$ \\
\hline & 22 & $68.7 \pm 4.9$ & $5852 \pm 298$ & $2.5 \pm 0.3$ & $33.2 \pm 8.0$ \\
\hline & 80 & $45.1 \pm 0.6$ & $4224 \pm 338$ & $2.5 \pm 0.4$ & $42.0 \pm 2.6$ \\
\hline \multirow{3}{*}{ PP10B10C } & -24 & $93.5 \pm 5.3$ & $10259 \pm 682$ & $2.4 \pm 0.4$ & $20.0 \pm 1.3$ \\
\hline & 22 & $73.0 \pm 2.2$ & $7074 \pm 356$ & $2.3 \pm 0.2$ & $25.9 \pm 7.0$ \\
\hline & 80 & $48.7 \pm 2.2$ & $4560 \pm 235$ & $2.4 \pm 0.1$ & $49.1 \pm 0.9$ \\
\hline
\end{tabular}



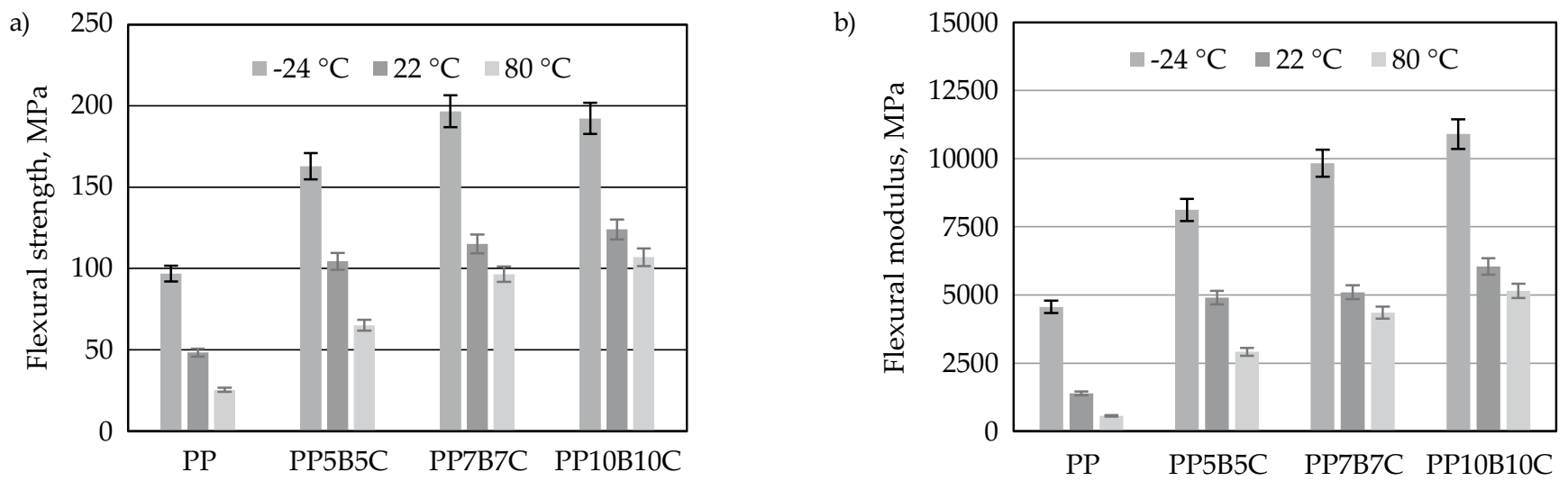

Fig. 1. Effect of basalt and carbon fibers content on: a) flexural strength, b) flexural modulus of PP and composites

a)

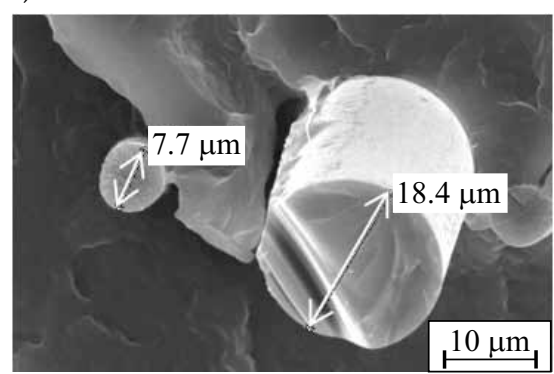

b)

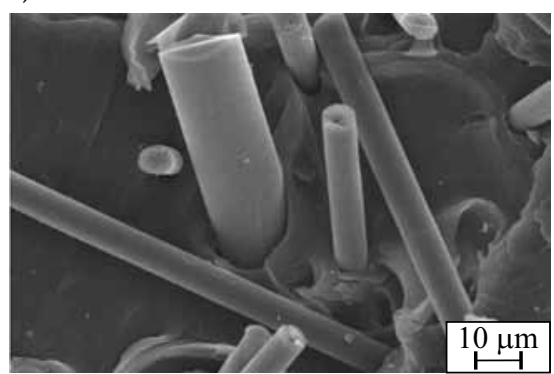

c)

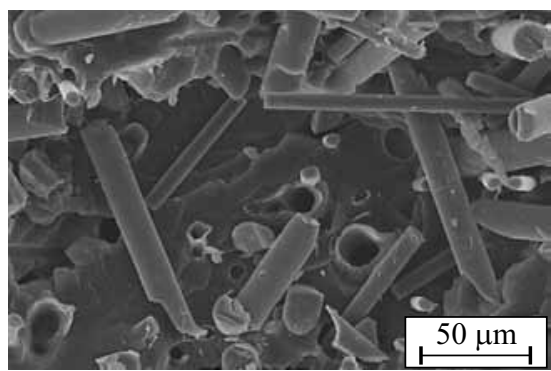

Fig. 2. SEM micrographs of tensile fractured surfaces of composites: a) PP5B5C, b) PP7B7C, c) PP10B10C

Mechanical properties were estimated by a tensile test (PN-EN ISO 527-1:2012) with a universal testing machine Criterion 043 with MTS axial extensometer. The test speed was set to $10 \mathrm{~mm} / \mathrm{min}$. The tensile modulus, tensile strength, and strain at break were determined. In addition to the tensile tests, three point flexural tests were also conducted for the compositions according to PN-EN ISO 178:2011 and flexural modulus as well as flexural strength were determined. Charpy impact test (PN-EN ISO 179-1:2010) was carried out on unnotched specimens using a Zwick HIT5.5P. The density of the materials was measured by a hydrostatic method. SEM structure images were made on the gold-sputtered tensile-test fracture surfaces of specimens using JEOL JSN5510LV. The softening point was determined by the Vicat method (PN-EN ISO 306:2014-02) using Ceast 6510.

\section{RESULTS AND DISCUSSION}

Basic characteristics of composites were presented in Table 1. Higher content of fibers resulted in an increase of density. Adding already $10 \mathrm{wt} \%$ of fibers resulted in an increase in Vicat softening point and a decrease in shrinkage value. Successive additions of fibers had a less significant impact on the measured values and elasticity modulus in a wide temperature range (Table 2). Addition of $10 \mathrm{wt} \%$ basalt/carbon fibers caused over two-fold increase in strength and four-fold increase in modulus of elasticity. The favorable effect of adding fibers is observed while determining properties at extreme operating temperatures of potential application. The impact strength decreases with the addition of fibers, nevertheless, much less than the strain at break. Results of bending test of the tested materials are shown in Fig. 1. The flexural strength of the tested composites is higher than their tensile strength probably due to the fibers orientation obtained during the injection molding process. Modulus of elasticity stays on the same level.

The addition of $10 \mathrm{wt} \%$ mixture of basalt fibers and carbon fibers is sufficient to allow the flexural strength to increase twice and the flexural modulus to increase four times. A further addition of fibers up to $20 \mathrm{wt} \%$ increases the strength and modulus by a further $25-30 \%$.

SEM was carried out to evaluate the state of dispersion and adhesion of both fibers into PP matrix. Micrographs of the fractured surfaces (Fig. 2) of tensile specimens are presented. Figure 2a shows a single fiber in PP matrix and measured diameter of $8 \mu \mathrm{m}$ of carbon and $18 \mu \mathrm{m}$ of basalt fibers. Figure $2 \mathrm{~b}$ suggests a good adhesion of both fibers in PP composites modified by MAPP. In the Fig. 2c we can observe 'pull out' fibers of the polymer matrix and, as a result, the strength of the composite with $20 \mathrm{wt} \%$ fiber content did not increase proportionally.

\section{CONCLUSIONS}

The addition of two types of fibers to the PP matrix with the participation of MAPP as a compatibilizer led to production composites with various microstructure, which had a positive impact on the strength properties of the obtained materials. Very good results - increasing the strength more than two times and increasing the elastic 
modulus more than three times were obtained by adding $5 \mathrm{wt} \%$ of basalt and carbon fibers. Further increase of carbon and basalt fibers up to $10 \mathrm{wt} \%$ in the composite resulted in over two and a half times increase in strength and a four-fold increase in the modulus of elasticity. The ratio of tensile strength to density of tested composites ranges from 62 to 70 and is comparable to carbon steel. In the tested composites, longer (200-300 $\mu \mathrm{m})$ and thicker (13-17 $\mu \mathrm{m})$ basalt fibers connect the remote areas of the polymer matrix improving impact strength and resistance to bending. Shorter $(50-100 \mu \mathrm{m})$ and thinner $(8 \mu \mathrm{m})$ carbon fibers connect the closer micro-areas which leads to improvement of tensile strength. These composites can be very attractive in technical applications such as critical components in automotive industry, load-bearing elements, load elements of household appliances or modern travel and sports equipment.

\section{REFERENCES}

[1] Fu S.Y., Lauke B., Mäder E. et al.: Composites Part A: Applied Science and Manufacturing 2000, 31, 1117. https://doi.org/10.1016/S1359-835X(00)00068-3

[2] Guo G., Chen J.C., Gong G.: Polymer Composites 2017, 1, 7. https://doi.org/10.1002/pc. 24350

[3] Swolfs Y., Gorbatikh L., Verpoest I.: Composites Part A: Applied Science and Manufacturing 2014, 67, 181. https://doi.org/10.1016/j.compositesa.2014.08.027

[4] Kada D., Migneault S., Tabak G. et al.: BioResources 2016, 11, 1393. https://doi.org/10.15376/biores.11.1.1393-1406

[5] Valente M., Sarasini F., Marra F. et al.: Composites Part A: Applied Science and Manufacturing 2011, 42, 649. https://doi.org/10.1016/j.compositesa.2011.02.004

[6] Al-Maadeed M.A., Shabana Y.M., Khanam P.N.: Materials \& Design 2014, 58, 374.

https://doi.org/10.1016/j.matdes.2014.02.044

[7] Turku I., Kärki T.: European Journal of Wood and Wood Products 2014, 72, 73. https://doi.org/10.1007/s00107-013-0754-8

[8] Jiang Z., Li S., Zeng J. et al.: Advanced Materials Research 2011, 189-193, 4043.

https://doi.org/10.4028/www.scientific.net/AMR.189193.4043

[9] Yan X., Cao S.: Composite Structures 2018, 185, 362. https://doi.org/10.1016/j.compstruct.2017.11.037

[10] Fiore V., Scalici T., Di Bella G. et al.: Composites Part B: Engineering 2015, 74, 74.

https://doi.org/10.1016/j.compositesb.2014.12.034

[11] Singha K.: International Journal of Textile Science 2012, $1(4), 19$. https://doi.org/10.5923/j.textile.20120104.02

[12] Greco A., Maffezzoli A., Casciaro G. et al.: Composites Part B: Engineering 2014, 67, 233. https://doi.org/10.1016/j.compositesb.2014.07.020

[13] Smith M.: Reinforced Plastics 2017, in press. https://doi.org/10.1016/j.repl.2017.07.004

[14] Newcomb B.A.: Composites Part A: Applied Science and Manufacturing 2016, 91, 262. https://doi.org/10.1016/j.compositesa.2016.10.018

[15] Sarasini F., Tirillò J., Ferrante L. et al.: Composites Part B: Engineering 2014, 59, 204. https://doi.org/10.1016/j.compositesb.2013.12.006

[16] Bunsell A.R., Harris B.: Composites 1974, 5, 157. https://doi.org/10.1016/0010-4361(74)90107-4

[17] Bandaru A.K., Patel S., Sachan Y. et al.: Composites Part A: Applied Science and Manufacturing 2016, 90, 642. https://doi.org/10.1016/j.compositesa.2016.08.031

[18] Siročić A.P., Hrnjak-Murgić Z., Jelenčić J.: Composite Interfaces 2009, 16, 85. https://doi.org/10.1163/156855409X402876

[19] Hassan A., Rahman N.Abd., Yahya R.: Journal of Reinforced Plastics and Composites 2011, 30, 1223. https://doi.org/10.1177/0731684411417916

[20] Zhang X., Yang H., Lin Z. et al.: Journal of Thermoplastic Composite Materials 2013, 26, 16. https://doi.org/10.1177/0892705711417030

Received 22 XII 2017. 